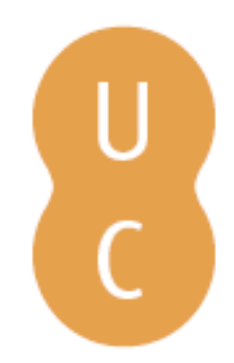

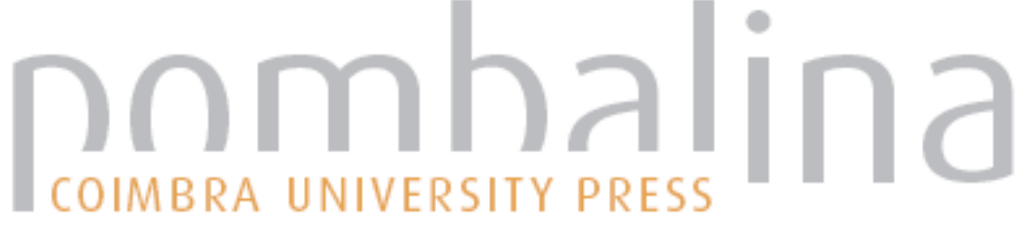

Atmospheric flow and a large fire interaction: the unusual case of Pedrogão Grande, Portugal (17 June 2017)
Autor(es):
Pinto, Paulo; Silva, Álvaro
Publicado por: Imprensa da Universidade de Coimbra
URL
persistente:
URI:http://hdl.handle.net/10316.2/44618
DOI:
DOI:https://doi.org/10.14195/978-989-26-16-506_101
Accessed : $\quad$ 26-Apr-2023 14:57:31

A navegação consulta e descarregamento dos títulos inseridos nas Bibliotecas Digitais UC Digitalis, UC Pombalina e UC Impactum, pressupõem a aceitação plena e sem reservas dos Termos e Condições de Uso destas Bibliotecas Digitais, disponíveis em https://digitalis.uc.pt/pt-pt/termos.

Conforme exposto nos referidos Termos e Condições de Uso, o descarregamento de títulos de acesso restrito requer uma licença válida de autorização devendo o utilizador aceder ao(s) documento(s) a partir de um endereço de IP da instituição detentora da supramencionada licença.

Ao utilizador é apenas permitido o descarregamento para uso pessoal, pelo que o emprego do(s) título(s) descarregado(s) para outro fim, designadamente comercial, carece de autorização do respetivo autor ou editor da obra.

Na medida em que todas as obras da UC Digitalis se encontram protegidas pelo Código do Direito de Autor e Direitos Conexos e demais legislação aplicável, toda a cópia, parcial ou total, deste documento, nos casos em que é legalmente admitida, deverá conter ou fazer-se acompanhar por este aviso.

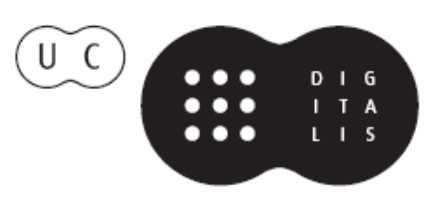




\section{ADVANCES IN}

\section{FOREST FIRE RESEARCH}

\section{8}

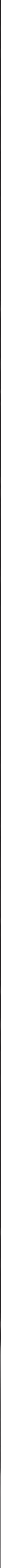




\title{
Atmospheric flow and a Large fire interaction: the unusual case of Pedrogão Grande, Portugal (17 June 2017)
}

\author{
Paulo Pinto*; Álvaro Silva \\ Instituto Português do Mar e da Atmosfera (IPMA), Lisbon, 1749-077, Portugal. \\ \{Paulo.Pinto@ipma.pt*\}
}

\begin{abstract}
On the afternoon of 17th June 2017 the fire was progressing in a hilly region of central mainland Portugal. A hot and dry atmosphere, characterized by a classic inverted V profile, typical from dry downburst environments (Weisman and Klemp, 1986), was in place, thus favoring high level based convection. In fact, an MCS that was observed both on satellite imagery and weather radar, has developed southeast of the fire area and, during the afternoon of this day, produced several downbursts that were recorded in several automatic weather stations (AWS). It was found that several shear lines, identified on Doppler radar, were considered to be consistent with convective outflow gust front surges that emanated from a downburst, or downbursts, generated by the MCS, and propagated over the fire area. It was verified that as this happened, the fire suffered an outstanding intensification, having produced a very violent and widespread firestorm that materialized an Extreme Fire Behavior (EFB), confirmed by ground survey (Viegas et al, 2017). As an outcome of this first interaction between the atmosphere and the fire, it was observed that a vertically developed dry pyroconvective column formed and made its way through the MCS anvil, placed overhead the fire by that time. Soon after, this smoke column top altitude decreased more than $5000 \mathrm{~m}$ in just 10 minutes. This remarkable behavior, resembling a downburst top collapse, was accompanied by a rapid low level plume displacement, interpreted as a result of the downburst induced circulation close to the ground. Just 10 minutes later, another fire blowup occurred, as the plume started to grow vertically. This second outstanding pyroconvective column growth was seen as a direct result of the stated downburst induced circulation at low levels that, as it was manifesting, induced another EFB episode.
\end{abstract}

Keywords: mesoscale convective system; outflows; shear lines; fire blowup; downburst; weather radar

\section{Introduction}

As recognized in specialized literature (Werth, P, et al, 2016), prolonged periods of drought are positively correlated with the occurrence of intense hot fires, although several studies (e.g. Viegas and Simeoni, 2011) have also clearly linked extreme fire behavior (EFB) with fuel properties and topography. The Pedrogão Grande (PG) large fire occurred in central mainland Portugal, after several months of under average rainfall records (April was the driest since 1931) and above average temperatures. By late May, more than two thirds of the country were in a severe drought level, according to Palmer Drought Severity Index (IPMA, 2017, in portuguese).

The PG large fire started during the early afternoon of the $17^{\text {th }}$ June 2017 . Less than one hour later, a second ignition originated a separate fire, a few kilometers far from the first location. By the same time, a multicell convective convective system (MCS) formed and started to propagate to the eastsoutheast of the fire area, in a very hot and dry low troposphere environment. It was observed, both on radar and ground stations, that several convective outflows were produced by the MCS. As the meteorological system was propagating closer the fire, some gust front surges started to interact with it and, on a certain occasion, a first outstanding fire intensification was observed. It materialized an EFB, as confirmed by ground survey. As it happened, the fire went out of control and more than 50 people were killed. 


\section{Data}

For the study of this interaction between the atmospheric flow and the fire, there were used ground, weather radar and lightning detection network observations. Numerical model data were also considered.

The area where the EFB occurred, referred to as PG fire area, is located in central mainland Portugal, as highlighted in Figure 1. Meteorological parameters from IPMA automatic weather stations (AWS) located in the fire area and surroundings (Figure 1) were analyzed, regarding air temperature, relative humidity and wind. The Tomar/Valdonas AWS was particularly important to validate a radar product that was used to diagnose the interaction. On the other hand, two C-band Doppler weather radars of the IPMA network were used (Figure 1). These were about $100 \mathrm{~km}$ far from the study area. The system installed to the north is a dual polarization (DP) radar, located at around $1100 \mathrm{~m}$ altitude (Porto radar, Figure 1). The system installed to the south is a single polarization system, located at around $200 \mathrm{~m}$ altitude (Lisboa radar, Figure 1). While the Porto radar did not perform observations below $1400 \mathrm{~m}$ altitude over the fire area, due to its large installation height, it was crucial in order to get a microphysical insight of the fire plumes, enabled by its DP capability. The Lisboa radar performed observations over the fire site, as low as $900 \mathrm{~m}$ altitude, although limited to single polarization moments. The real resolution of radar observations was about $1 \mathrm{~km}$ over the fire area, both in azimuth and range, matching a nominal cartesian resolution of the same magnitude. Reflectivity, Doppler velocity and several DP moments were used in this study. The analysis of the fire-atmosphere interaction evolution was mainly based on the use of single PPI's and vertical sections of radar observations. The vertical sections were performed over a segment that is referenced to in Figure 1. Nine lightning detection sensors were accessed, 3 of them operated by IPMA and the remaining by AEMET (Spanish Meteo Service), installed close to the Portuguese border. The nearest 4 of these 9 sensors are represented in Figure 1.

The vertical thermodynamic structure of the atmosphere was analysed, both using observed atmospheric profiles (rawinsonde data from 08579 Lisboa station, $17^{\text {th }}$ June, 12 UTC, not shown) and vertical profiles obtained from numerical model processing. From these, a vertical profile from 18 UTC (19:00h, local time) from the Pedrogão Grande location (Figure 1) was extracted and discussed.

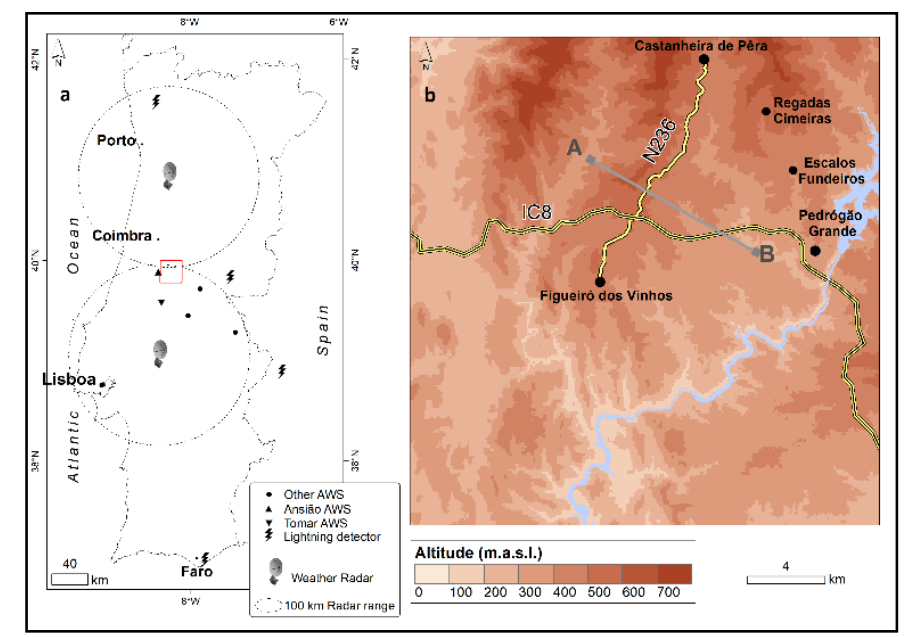

Figure 1 - Parts of western Iberia a) and zoomed Pedrogão Grande Fire area b). a) Fire area (red square) zoomed in b), relevant automatic weather radar stations, 4 of the 9 nearest lightning used sensors and weather radar stations. $b$ ) terrain, important locations and roads, numerical model profile point (Pedrogão Grande), relevant fire ignitions at Escalos Fundeiros and Regadas; radar transect (A-B) segment referred to in the text. $100 \mathrm{~km}$ radar ranges are marked for reference. 


\section{Meteorological environment}

By 13:00h local time, $17^{\text {th }}$ June 2017, the ECMWF mean sea level pressure analysis was showing a high pressure system centered over southern England (Figure 2) and, to the south of it, a thermal trough pattern over western Iberia, in association with the typical Iberian thermal low. This was promoting a weak easterly flow over mainland Portugal. Offshore northern Morocco there was an upper level low, significant just above $700 \mathrm{hPa}$ (not shown). During early afternoon, a cool air advection in the 700-500 hPa layer (not shown) that was driven by the stated high pressure system, and the strong low level heating, increased the atmospheric instability. By 16:00h local time, as shown by ECMWF data, a short forecast was showing some humidity convergence at mid levels over central mainland Portugal (Figure 3).

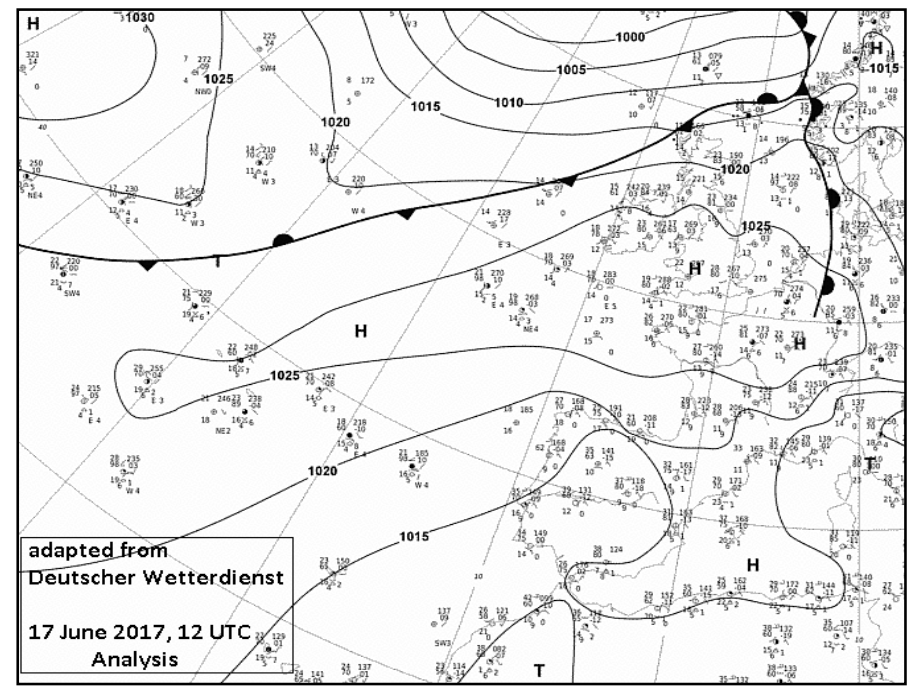

Figure 2 - Mean sea level pressure (solid contours, 5 hPa intervals) over northeast Atlantic; analysis adapted from Deutscher Wetterdienst, 13:00h, local time, $17^{\text {th }}$ June 2017.

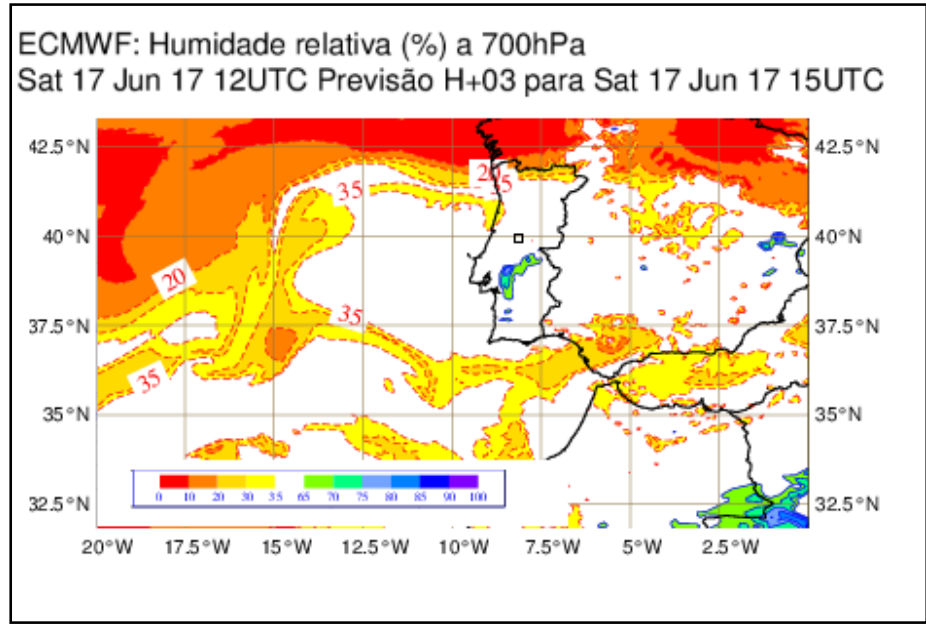

Figure 3 - Relative humidity (color shaded, \%) at 700 hPa over Iberia and northern Morocco, ECMWF forecast for 16:00h, local time. $17^{\text {th }}$ June 2017.

A vertical atmospheric profile valid at 19:00h was derived from ECMWF short term forecasts (Figure 4), for a point located a few kilometers east of the fire perimeter. This profile showed a hot and dry low troposphere, resembling the classic "inverted V" profile, typical from dry downburst environments (Weisman and Klemp, 1986). Above $700 \mathrm{hPa}$ the atmosphere was unstable. Total precipitable water was around $30 \mathrm{~mm}$. This was consistent with an environment prone to high level based convection to the southeast of the fire area. 


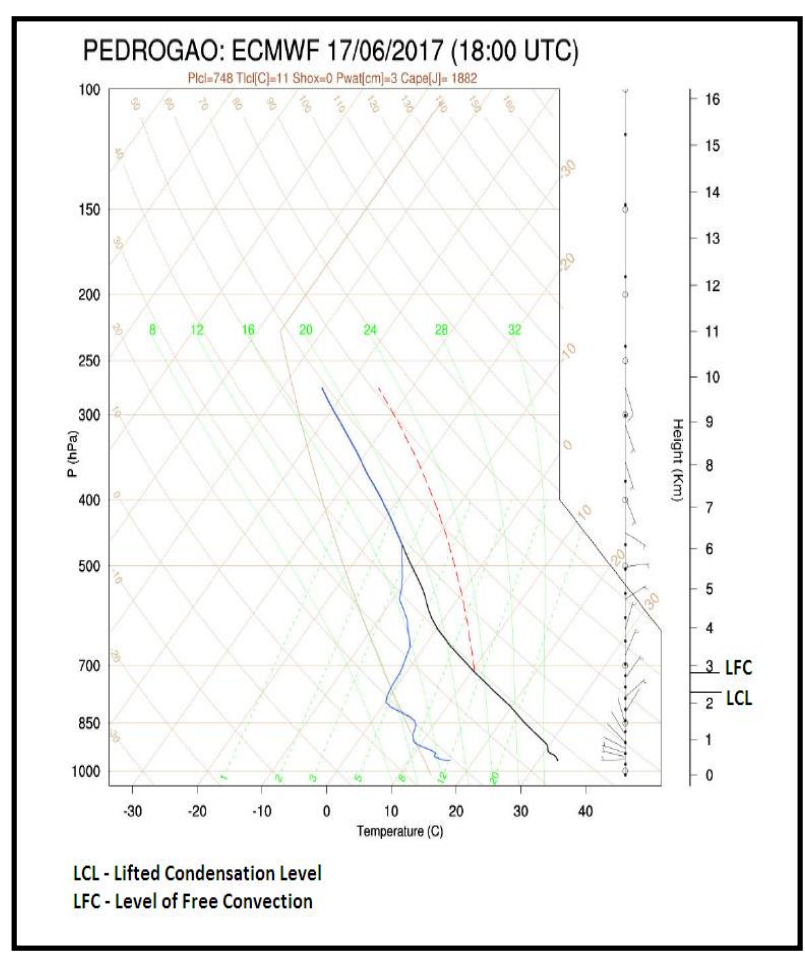

Figure 4 - SkewT chart (ECMWF profile) for the Pedrogão Grande area at 19:00h, local time, $17^{\text {th }}$ June 2017. Dry bulb air temperature (black curve, to the right), dew point temperature (blue curve, to the left) and parcel trajectory (dashed orange curve) are represented. Wind barbs at different levels also represented. LCL and LFC are depicted over the height scale.

As revealed both by observations derived from the Lisboa radar scans and satellite imagery, a multicell convective system was propagating over central-southern mainland Portugal (Figure 5) during the afternoon of the $17^{\text {th }}$ June. By $18: 30 \mathrm{~h}$, the system was already entering a dissipating stage, clearly visible by a developed and extensive anvil, spawned for many thousands of squared kilometers. Its signature was remarkably visible on satellite, over the area where the fire was progressing (Figure $5 b)$. Nevertheless, by this time, the radar was showing several convective core signatures, consistent with the multicell nature of the convective system (Figure 5a).
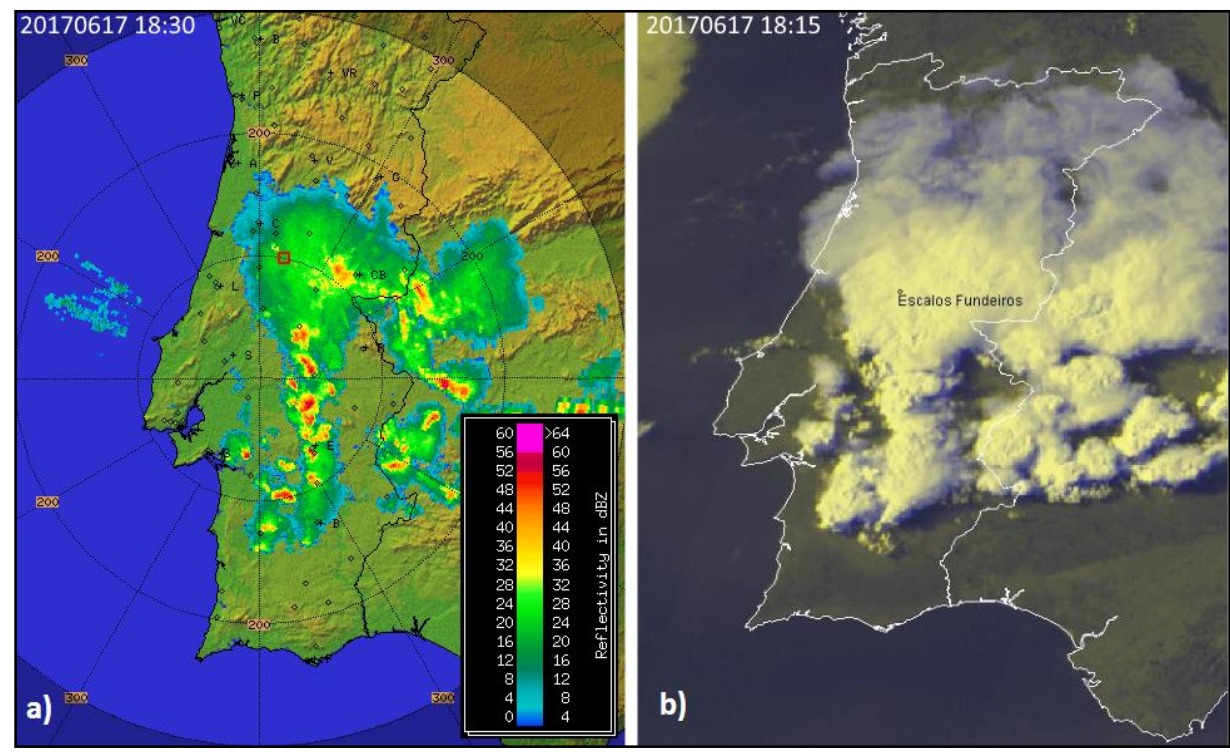

Figure 5 - a) Maximum returns of reflectivity (dBZ) for 18:30h, local time, Lisboa radar. Fire area marked with a red square (over the northern end of $100 \mathrm{~km}$ range). A large circular reflectivity pattern corresponds to an extensive anvil signature; b) High resolution visible MSG image for 18:15h, local time. Location Escalos Fundeiros (Fire area) is marked. $17^{\text {th }}$ June 2017.

As frequently observed, some atmospheric environments can be supportive of both wet and dry downbursts. On the $17^{\text {th }}$ June the situation was of this type, in accordance with several reports and 
records on film (not shown). This atmospheric environment, prone to downbursts did, in fact, develop several of these phenomena that were observed in a number of IPMA AWS and on Doppler radar.

\section{Convective outflows}

More frequently than recognized during the past decades, convectively-cooled air from small scale convective perturbations may impact the ground levels. Usually, the surface boundary (marked by a gust front) formed by the horizontal spread of such cooled air, does not play a significant role. Nevertheless, provided the required ingredients are in place, convective outflow boundaries may act as sources of secondary convection and even present hazardous conditions to aircrafts takeoff and landing. In extreme cases these outflows may generate large turbulent regime flows, especially in the area of the gust front, where sudden wind direction and intensity may be expected. These conditions may persist even at far ranges of the originating convective system.

\subsection{Gust front detection in favorable conditions}

The atmospheric volumes where a convective outflow leading edge is propagating may, or may not, be favorable to the detection on a weather radar perspective. When scatterers, such as insects, are well distributed throughout the observational volumes, thin reflectivity lines and Doppler signatures (Klingle and Smith, 1987) may be detectable and allow the diagnostic of low level convergence lines (or shear lines) associated with the gust fronts. This was the case in the region located to the south and southwest of the multicell system (not shown), in an early stage, as the system was developing, still to the southeast of the fire area. However, radar reflectivity analysis may render useless if scatterers are poorly distributed in the observed volumes. Furthermore, Doppler velocity signatures of these gust fronts may also be very hard or impossible to identify, due to the lack of scatterers and the complexity of signatures, themselves. This unfavorable detection environment was found in the area located between the convective system cores and the fire location, just before the largest interaction took place. This fact required a non-standard approach.

\subsection{Gust Front detection in unfavorable conditions}

A fine tune calibration of a low level PPI of horizontal shear (azimuthal and radial shear) was performed, so that any shear lines propagating, eventually, over the fire area could be identified even in unfavorable conditions. This calibration was achieved using several AWS data located in the favorable detection area. If the validity of this non-standard radar product would be confirmed in the favorable detection area, its use during the afternoon of this day would be extended to the required unfavorable detection area.

It was found an optimal fine tune situation by directly comparing a PPI of shear with a simultaneous PPI of reflectivity (Figure 6). In the example of Figure 6a the subjectively detected fine line of reflectivity, using space and time coherence criteria, is represented. In Figure 6b, over the horizontal shear field, a line showing space and time coherence on radar, matching the one already identified in Figure $6 \mathrm{a}$, was represented. In this example, by 18:06h, the identified line was propagating westerly and very close, but still to the east, of the Tomar AWS (Figure 6). Meanwhile, just before 18:20h, the AWS observations, 10 minutes average, were showing a $2 \mathrm{~m}$ air temperature over $40^{\circ} \mathrm{C}$ and a relative humidity close to $20 \%$, typical of the low level atmospheric environment of that day (Figure 7). Then, by $18: 20 \mathrm{~h}$, a sudden temperature decrease and relative humidity increase started, followed by an easterly gust of $15 \mathrm{~m} / \mathrm{s}$, shortly after. This evolution was absolutely consistent with the propagation of a density current over the station. This calibrated horizontal shear field, tested against other ground observations (not shown) was considered as a reliable tool for the identification of the shear lines in hard observational conditions. 
The diagnose of shear lines was especially difficult in the vicinity of the fire area, due to the stated lack of scatterers and to an unfavorable beam orientation of the Lisbon radar over there. In fact, to the southeast of the fire area, the beam was facing the main flow (from the east-southeast) at an unfavorable right angle.

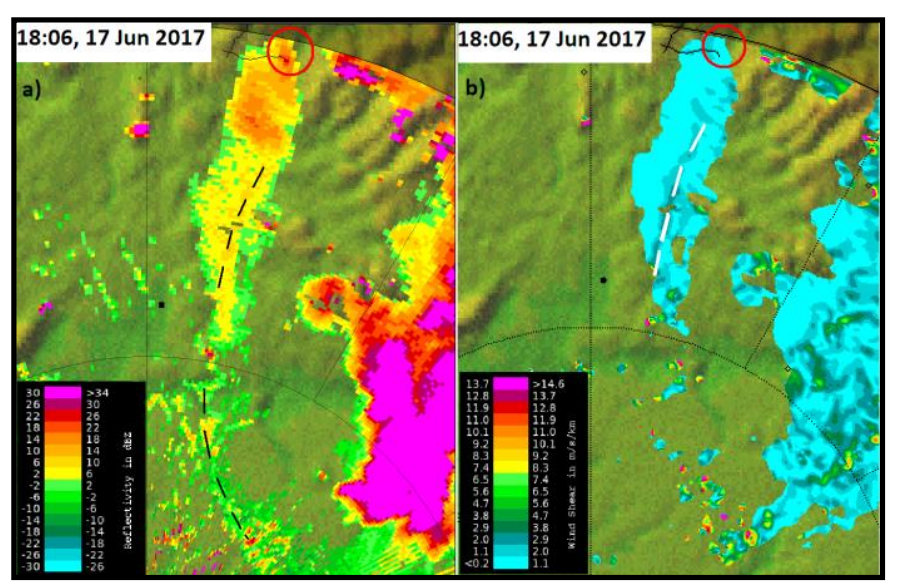

Figure 6 - Plane position indicator, $0.1^{\circ}$ elevation, 18:06, $17^{\text {th }}$ June 2017, Lisboa radar for a) reflectivity (-30 to $>30 \mathrm{dBZ}), \mathrm{b})$ horizontal shear (radial and azimuthal) $(0$ to $>14,6 \mathrm{~m} / \mathrm{s} / \mathrm{km})$. A shear line signature is marked with a dashed black line in a) and a dashed white line in c). Tomar AWS location is marked with a black dot. Fire plume area (low level) by 18:06, is marked with a red circle. Radar observations over the fire area are performed at $900 \mathrm{~m}$ altitude (radar site to the bottom of the image).

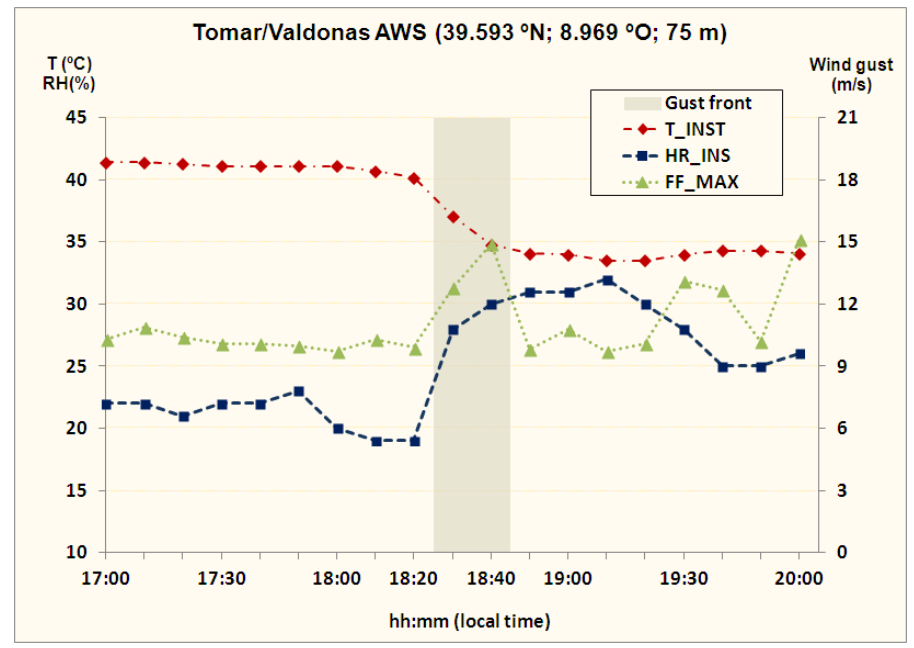

Figure 7 - Tomar/Valdonas AWS observations: $2 \mathrm{~m}$ air temperature (red), $2 \mathrm{~m}$ relative humidity (dark blue), $10 \mathrm{~m}$ wind gust (green), 17:00-20:00h, local time, 17 th June 2017. The vertical shaded bar (18:25-18:45) signs the onset of the convective outflow over the AWS.

\section{Fire-atmosphere interaction}

The Lisboa radar was very helpful to follow up the fire-atmosphere interaction, at low levels. It performed observations as low as $900 \mathrm{~m}$ altitude over the study area, where the average ground was about $400 \mathrm{~m}$. The lowest level PPI of reflectivity enabled the identification of relevant maximum reflectivity patterns. These, if showing vertical consistency with upper level PPI's, were considered as fine identifiers of the approximate low level pyroconvective plume position ( $900 \mathrm{~m}$ altitude). So, the fire-atmosphere interaction was, in fact, studied from a pyroconvective plume-atmosphere interaction perspective. Radar reflectivity is proportional to the first power of the number of scatterers in an observation volume and to the sixth power of their diameter. Thus, larger reflectivity values at low 
levels are positively correlated with more intense burning processes at ground levels. Vertical sections using several PPI's were also used.

On the other hand, the Porto radar was used to diagnose the microphysics of the observed atmospheric volumes. During the more relevant pyroconvective plume-atmosphere interaction stage, as it will be shown, the plume made its way through the anvil of a convective system that was, then, in place above the fire. A distinction between the approximate boundaries of the smoke plume and the ones of the intervening meteorological system was crucial. A useful DP parameter, the correlation coefficient $\left(\rho_{\mathrm{hv}}\right)$, was used, as it is considered a fine particle type discriminator (Balakrishnan and Zrnic, 1990). It corresponds to a correlation coefficient, in time series, between horizontally and vertically polarized echoes. Recently (Lang et al, 2014; LaRoche and Lang, 2017) it was found that a mixture of fire ash and rimed ice uses to show $\rho_{\text {hv }}$ values larger than or equal to 0.8 , whereas pure ash uses to feature $\rho_{\mathrm{hv}}$ values lower than 0.8 . So, it was roughly considered that volumes presenting $\rho_{\mathrm{hv}}$ values less than 0.8 were typical from the dry pyroconvective plume.

\subsection{Stage 1: 14:30h-19:15h}

The PG fire started by 14:30h, near Escalos Fundeiros (Figure 1). A second ignition occurred close to Regadas Cimeiras (Figure 1), reported by 15:40h and originating a separate fire, less than $3 \mathrm{~km}$ apart from the first location. By this time the low level wind was weak and blowing from the northwest, as revealed by video camera recordings and AWS stations (not shown). As mentioned before, a multicell convective system started to propagate over central-southern mainland Portugal by this time.

During the first few hours of this stage, the fire-atmosphere interaction did not produce remarkable effects. After 18:00h, though, the approaching convective system started to increase its influence, as a stronger southeast flow, at low levels, became predominating. Several fire intensifications were, then, observed on radar, as the fire plume pattern showed transient, although not very spectacular, increase on its reflectivity and vertical extension (not shown). These intensifications were also confirmed by ground survey (Viegas et al., 2017, in portuguese) and video camera recordings.

\subsection{Stage 2: 19:15h-20:00h}

Radar observations have shown that the pyroconvective column, inspected along the transect segment marked in Figure 1, started to suffer a huge growth by 19:20h (Figure 8) having peaked by 19:50h (Figure 9), as it topped at $12500 \mathrm{~m}$ altitude. During this outstanding development, it is perfectly illustrated in Figure 10 that the pyroconvective column ( $\rho_{\text {hv }}$ values $<0.8$, in greenish color), made its way through the convective system deep anvil ( $\rho_{\text {hv }}$ values $>0.8$, in yellowish color). The anvil was more than $3000 \mathrm{~m}$ below the one of the column top (Figure 8).

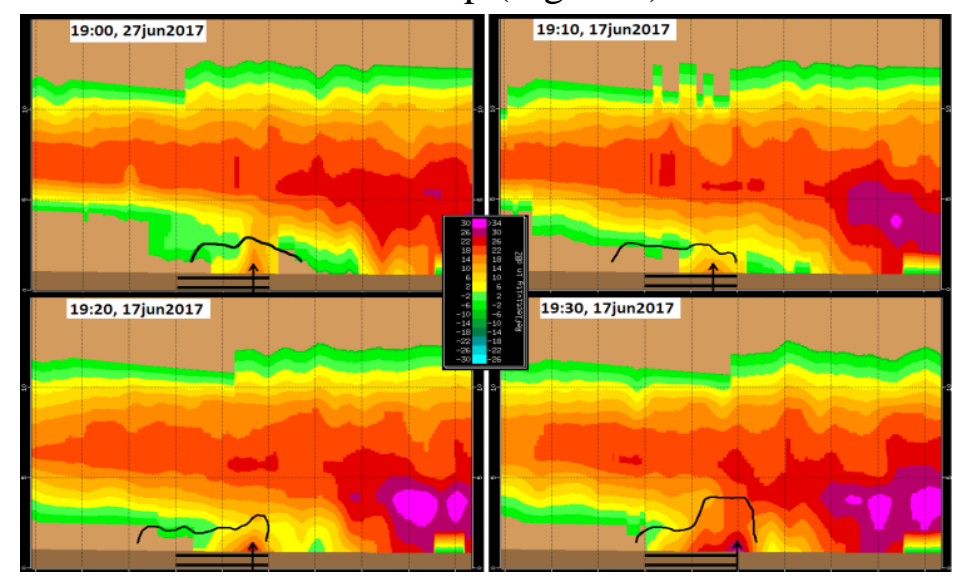

Figure 8 - Vertical cuts on reflectivity (-30 to $>34 \mathrm{dBZ})$, Lisboa radar, June $17^{\text {th }} 2017$ (19:00h-19:30h). Section is along the segment marked in Figure 1, observer looking from the south (horizontal double lines mark the transect itself). Black arrow represents the plume location at $900 \mathrm{~m}$ altitude. Black contour represents 0.8 phv value (dry smoke threshold). Vertica/horizontal scales, $5 \mathrm{~km}$ discretization. 


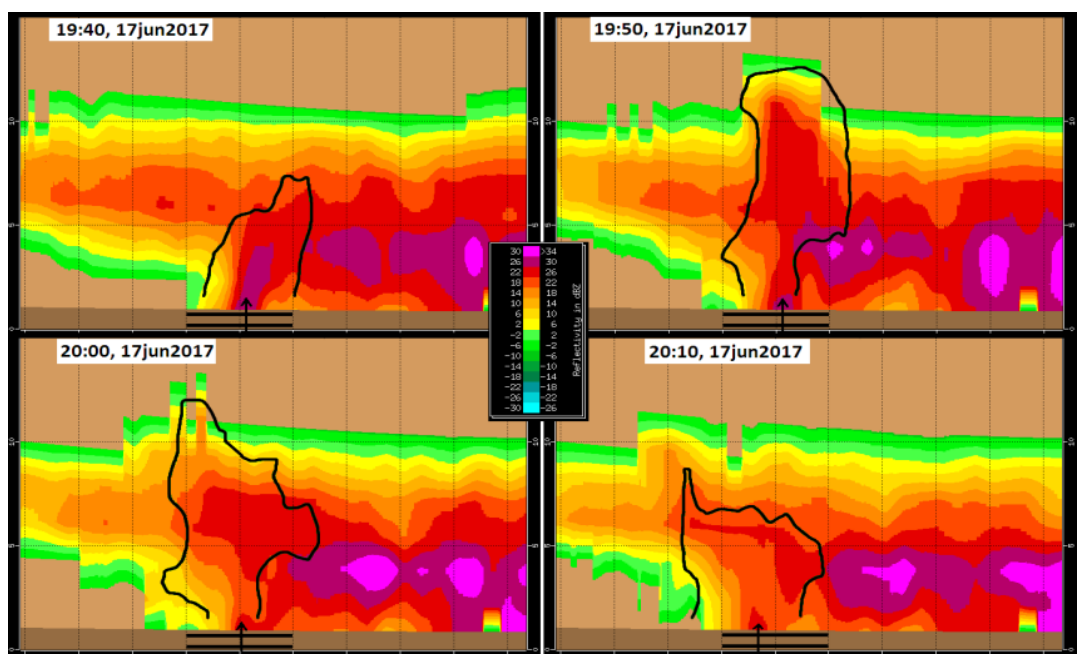

Figure 9 - Vertical cuts on reflectivity (-30 to $>34 \mathrm{dBZ})$, Lisboa radar, June $17^{\text {th }} 2017$ (19:40h-20:10h). Section is along the segment marked in Figure 1, observer looking from the south (horizontal double lines mark the transect itself). Black arrow represents the plume location at $900 \mathrm{~m}$ altitude. Black contour represents $0.8 \rho_{h v}$ value (dry smoke threshold). Vertical/horizontal scales, $5 \mathrm{~km}$ discretization.

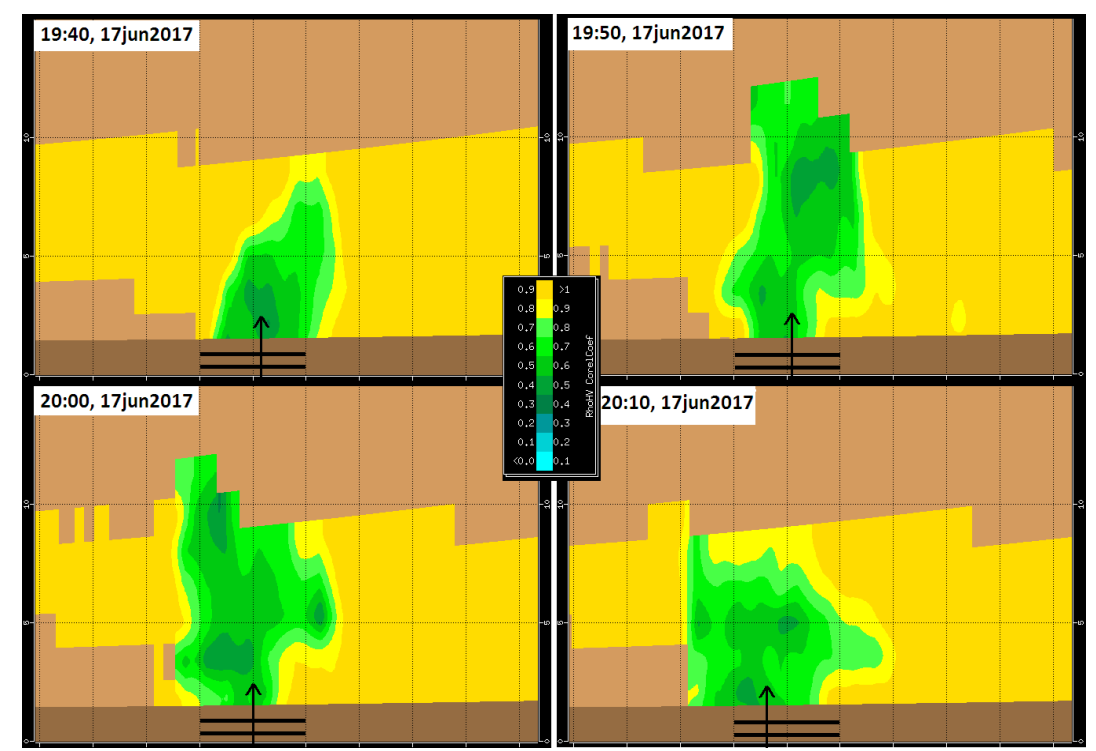

Figure 10 - Vertical cuts over the correlation coefficient field ( 0 to1), Porto radar, June $17^{\text {th }}$ 2017 (19:40h-20:10h). Section is along the segment marked in Figure 1, observer looking from the south (double lines mark the transect itself). Black arrow represents the plume location at $1100 \mathrm{~m}$ altitude. Greenish colors represent $\rho_{h v}<0.8$ (dry smoke threshold). Vertica/horizontal scales, $5 \mathrm{~km}$ discretization.

The atmospheric volumes upwind of the fire area were inspected using radar observations, starting at a considerable time before the observed fire behavior modification. These observations corresponded to the calibrated horizontal shear product (see 4.2). Using this product, no coherent shear lines were identified on radar between $18: 10 \mathrm{~h}$ and 18:50h. However, by 18:56h, a shear line was detected, to the southeast of the fire (Figure 11a; the fire area for reference is the one of the low level fire plume area observed on radar by 19:16h). By 19:06h and 19:16h this line and another one, to the northwest of it, could be identified, while propagating towards the fire area (Figures 11b, c). By 19:26h the first detected shear line became more visible (Figure 11d) and by 19:36h could be clearly identified over a larger area (Figure 11e). More shear lines were detected to the southeast of the fire area, especially by 19:36h, although less defined (not marked).

All these shear lines resemble the ones previously mentioned (section 4.2) and propagated to the west/northwest, in a direction coherent with a divergent outflow, or outflows, emanated from a 
downburst, or downbursts, that were generated on the multicell system that was propagating from the southeast, towards the fire area. It is considered that these lines were directly associated with gust front surges that interacted with the fire.

While these shear lines were propagating at low levels, the fire was evolving on the terrain. As revealed by a detailed study (Viegas et al., 2017, in portuguese) it was verified that by 19:30h and slightly before, the two fires (Escalos and Regadas) were still separated, but with the corresponding fronts very closely organized. Two separate fire columns existed at that time, according to available photos (Viegas et al., 2017, in portuguese). According to the same study, the fires merged shortly after 19:30h and an EFB has started.

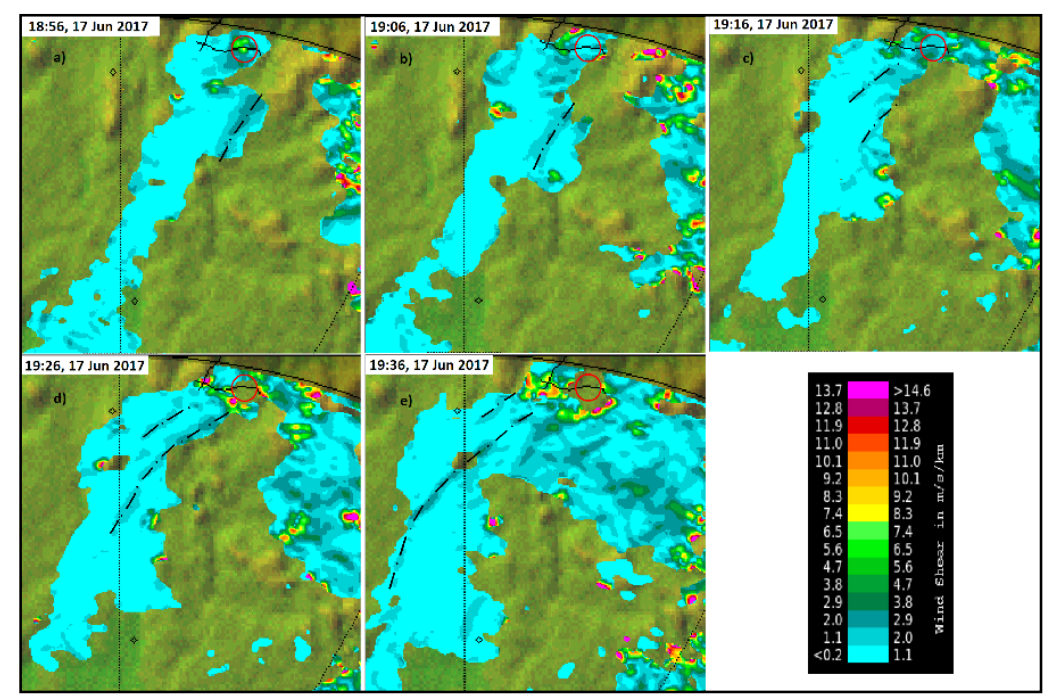

Figure 11 - Plane position indicator, $0.1^{\circ}$ elevation, 18:56h-19:36h, local time, $17^{\text {th }}$ June 2017, Lisboa radar, for horizontal shear (radial and azimuthal, $\mathrm{m} / \mathrm{s} / \mathrm{km}$ ). Shear line signatures are marked with black dot dash lines. Fire plume area (low level) by 19:16h reference, is marked with a red circle. Radar observations over the fire area are performed at $900 \mathrm{~m}$ altitude (radar site to the bottom of the images).

The pyroconvective plume position, at $900 \mathrm{~m}$ altitude, was identified by its radar reflectivity maximum values (section 5.). Since these are positively correlated with the corresponding fire intensity, the time evolution of those maximum was followed, between 17:00h and 19:50h. Figure 12 shows that there were several fluctuations during the considered period. But the fact is that from 17:00h to 19:06h the fluctuations were not very impressive. They were consistent with the already mentioned fire intensifications, confirmed by ground survey and video camera recordings, during the same period (Viegas et al., 2017, in portuguese). However, between 19:06h and 19:16h, it was observed a huge increase in the maximum reflectivity values, sustained afterwards and consistent with the onset of an EFB. In fact, taking into account that the average value of the plume maximum reflectivity increased from $21 \mathrm{dBZ}$, before the interaction, to $34 \mathrm{dBZ}$, after it (Figure 12) and that this unit is logarithmic, this increase rises to several orders of magnitude if linear units are considered. This 10 minute period was the first in which two shear lines (representing gust front surges) were detected very close to the fire area (Figure 11c). This interaction, by 19:16h, was in place 15 minutes before the reported fires merging and was seen as a cause for the two fires intensification, a forcing element that drove an increase in their rate of spread and, ultimately, to their merging, slightly after 19:30h. Afterwards, an EFB occurred, and an enormous area was burned in a few minutes. 


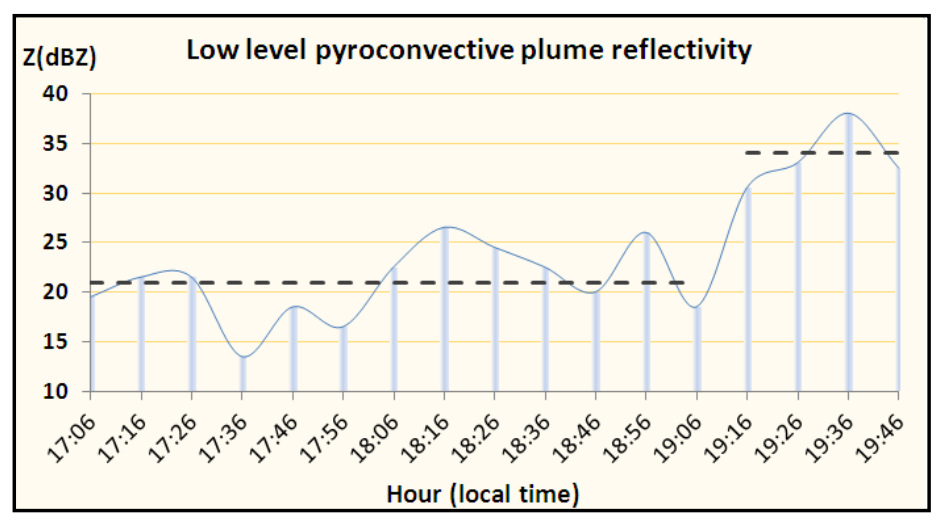

Figure 12 - Pyroconvective plume maximum reflectivity values (dBZ) at 900m altitude, 17:00h-19:50h, 17 June 2017, Lisboa radar observations. The horizontal dashed segments represent average values during 17:00h-19:10h - $21 \mathrm{dBZ}$ - and 19:15h-19:50h - $34 \mathrm{dBZ}$. The difference between 21dBZ and $34 \mathrm{dBZ}$, logarithmic units, are several orders of magnitude in original (not represented) linear units.

\section{Final remarks}

This study has treated a case in which a multicell convective system, propagating in a very hot and dry low troposphere environment, revealed to be a prolific downburst producer. This system propagated from the southeast, towards a forest fire, that was in place over central mainland Portugal. The fire initiated by $14: 30 \mathrm{~h}$, local time, of $17^{\text {th }}$ June 2017 . A second ignition produced another fire, a few minutes later, less than 3 kilometers far from the first ignition. The fire area was, initially, under a weak low level flow but, as the convective system approached, this flow intensified and several interactions with the fire were observed. No significant interactions occurred before 19:10h according to radar analysis. However, from 18:50h onwards, several shear lines were detected at low levels, propagating upwind of the fire and towards it (Figure 13). These lines were coherent with divergent outflows emanated from a downburst, or downbursts, generated on the convective system. This study showed that the lines corresponded to gust front surges that started to strongly interact with the fire, about 15 minutes before the observed fire behavior modification, so around 19:15h. These first gust front surges were considered as an important factor for the fires intensification and, in the end, for their merging, after $19 \mathrm{~h} 30$.

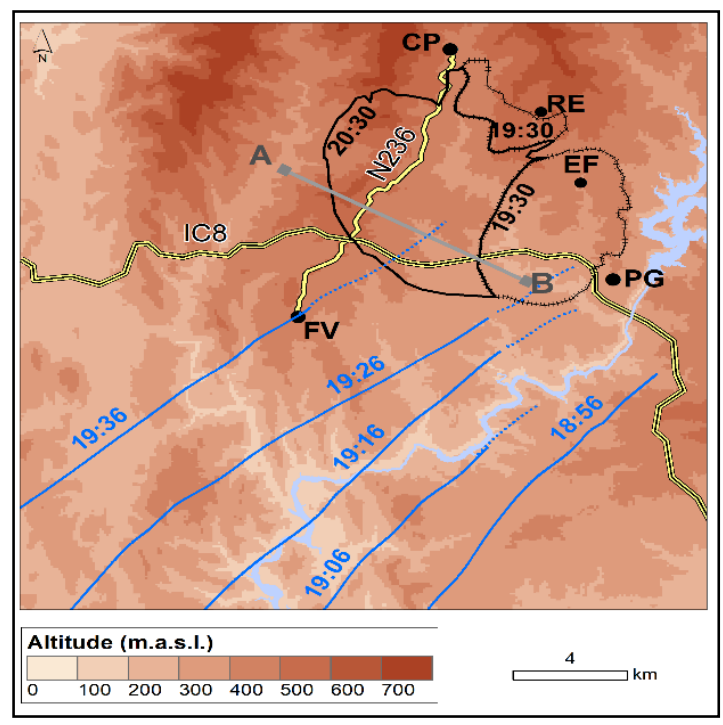

Figure 13 - Pedrogão Grande Fire area (zoomed in, Figure 1). Terrain, important locations (CPCastanheira de Pera, RE - Regadas, EF-Escalos Fundeiros, PG-Pedrogão Grande and FV-Figueiró dos Vinhos) and roads, relevant fire ignitions ( $E F$ and $R E)$; radar transect $(A-B)$ referred to in the text. Fire fronts position estimated by 19:30h and 20:30h (adapted from Viegas et al, 2017) marked in black contour. Shear line, as detected on radar, time stamped in blue color. 
As the fires merged, an EFB started and a large area was quickly burned. This EFB was conceptually explained on another study (Viegas et al., 2017, in portuguese). The topography of the area in between the fire front position estimated at 19:30h, and the N236 road, shows two canyons, clearly visible (Figure 13). The relative orientation of the gust fronts in respect to these canyons, suggests a small angle between the predominant gusty winds of the outflow (from the southeast, roughly at right angle to the gust fronts) and the canyons orientation. This may have contributed to locally intensify the flow and, thus, foster the interaction with the fire.

The complex interaction phenomena between the flow and the fire, was not limited to this first fire blowup. By 20:00h-20:10h a sudden decrease of the pyroconvective plume top was noticed on radar. This decrease, resembling a downburst of the smoke plume itself, is still of undetermined origin. According to weather radar data analysis, this phenomenon produced another activation of the fire and, as a consequence, a $13000 \mathrm{~m}$ altitude convective plume was produced in a very short time period. This convective plume collapse and consequent pyroconvection activation will be object of another study.

\section{References and bibliography}

Balakrishnan, N., and Zrnic, D., 1990: Use of Polarization to Characterize Precipitation and Discriminate Large Hail, Journal of the Atmospheric Sciences, Volume 47, No. 13, 1525-1540.

IPMA, 2017: Boletim Climatológico junho 2017, Portugal Continental, ISSN 2183-1076 (in portuguese).

Klingle, D., and Smith, D., 1987: Gust Front Characteristics as Detected by Doppler Radar, Monthly Weather Review, Volume 115, 905-918.

Lang, T., B. Dolan, P. Krehbiel, W. Rison, and D. T. Lindsey, 2014: Lightning in wildfire smoke plumes observed in Colorado during summer 2012. Monthly Weather Review, 142, 489-507.

LaRoche, K., and Lang, T., 2017: Observations of Ash, Ice, and Lightning within Pyrocumulus Clouds Using Polarimetric NEXRAD Radars and the National Lightning Detection Network, Monthly Weather Review, Volume 145, 4899-4910.

Viegas, D. X., M. F. Almeida, L. M. Ribeiro, J. Raposo, M. Viegas, R. Oliveira, D. Alves, C. Pinto, H. Jorge, A. Rodrigues, D. Lucas, S. Lopes and L. F. Silva, 2017: O complexo de incêndios de Pedrogão Grande e Concelhos Limítrofes, iniciado a 17 de Junho de 2017. ADAI/LAETA, Dep. Eng. Mecânica, F. C. T., Universidade de Coimbra (in portuguese).

Viegas, D. X., and Simeoni, A., 2010: Eruptive behaviour of forest fires. Fire Technology. 47(2): 303.

Weisman, M. L., and Klemp, J. B., 1986: Characteristics of isolated convective storms. Mesoscale Meteorology and Forecasting, P. S. Ray, Ed., Amer. Meteor. Soc., 331-358.

Werth, P, et al., 2016: Synthesis of Knowledge of Extreme Fire Behavior, Volume 2 for Fire Behavior Specialists, Researchers, and Meteorologists, USDA, 260 pp. 